\title{
City Scale Vs. Regional Scale Co-Benefits of Climate and Sustainability Policy: An Institutional Collective Action Analysis
}

\author{
Richard Clark Feiock* \\ Local Governance Research Lab, USA
}

Submission: September 23, 2020; Published: October 15, 2020

*Corresponding author: Richard Clark Feiock, Director, Local Governance Research LLC, 418 East 9th Ave, Tallahassee, FL 32303, USA

Keywords: City Scale; GHG emissions; Regional; Environmental; ; Climate protection; Climate change; Electricity consumption

\section{Short Communication}

Multiple levels of government must play complementary roles in mitigating climate changes [1,2], but city level engagement and action are particularly critical for two reasons. First, urban areas are the primary source of GHG emissions worldwide. For example, in the US, urban areas hold over three-fourths of the population and account for about $80 \%$ of global primary energy use and greenhouse gas (GHG) emissions [3]. Second, cities have the potential to significantly influence environmental and problems since they have primary responsibility for the local land use and building decisions that are critical to sustainability efforts. In many countries' cities have stepped up to address climate and GHG mitigation issues. City leadership in climate protection is especially visible in the US due to the absence of action by the national level government, but cities have been leaders in nations across the globe.

On the face local efforts to address climate change appear to be non-rational. GHG emissions is a global commons phenomena and efforts to mitigate it by individual cities defies the logic of collective action which predicts that local governments will free ride on the efforts of others [4]. The Logic of Collective Action [4] predicts that local governments will not voluntarily invest in climate change efforts. Instead, cities are expected to free ride on the efforts of other governments, because a city's contribution to the collective good is minimal and the benefits generated are nonexcludable (that is, the benefits are impossible to compartmentalize and deny to others). Carbon emissions in particular are global pollutants, so local residents share any environmental benefit with every living being on the planet. Thus, the rapid adoption and diffusion of city-level energy and climate-protection policies, in the absence of strong state or federal incentives to do so, pose a curious puzzle for social science theories of policy adoption and collective action. Why do local officials pursue climate policy initiatives when the benefits must be shared?

How then do cities pursue climate mitigation policies when the benefits must be universally shared? First, local governments are uniquely positioned to address a range of activities that directly contribute to climate change, from land use to electricity consumption. Municipal governments have tools to directly address energy efficiency, conservation, and carbon emissions through their well-established role in land use and service delivery. Despite local governments' ability to take the lead on energy and climate issues, there is very little scholarship examining what factors account for local adoption of sustainability programs.

Second, local officials are able to overcome collective action problems if sustainability programs produce local, communityspecific benefits such as the reduction of energy costs, pollution, and traffic congestion. Sustainability programs can also be a tool to attract economic development, protect environmental amenities, and enhance community health and livability. Thus, scholars have claimed to solve the collective action paradox of city sustainability policy, by identifying local co-benefits of climate action for cities. For example, programs and policies to mitigate GHG emissions are argued to produce substantial economic, social, public health, fiscal and political co-benefits generated by climate protection that benefit individual cities [5].

This insight misses the reality that many of these "local" benefits are realized at a regional or metropolitan level, not at the city level. The literature on local benefits treats the value of sustainability and climate policy actions either as global 
on the one hand, or city specific on the other, leaving out the role of subnational regions in shaping the benefits and costs of sustainability actions to individual cities.

Regional collaboration among cities can reduce both the costs of production and the transaction costs of policy actions. Efficiencies can also be realized in the coordination of infrastructures and other investments. Information on best products and practices, and on vendors and contractors, enhances benefits and reduces costs. In addition, coordination of the timing of action or jointly purchasing technologies and equipment can produce economies of scale. Also, many of the co-benefits that climate policy produce are regional though, not global, externalities [5]. Examples include reduced congestion and commuting times, air pollution and improved water quality.

The issue of scale is particularly salient. To what extent does the spatial or geographic scale of sustainability problems match to the spatial areas defined by local government boundaries? Scale issues are critical to understanding why cities initially engage in climate protection efforts. Cities are finding that environmental sustainability and GHG mitigation requires engagement in collaborative networks to coordinate action across cities, governmental and non-governmental organizations and multiple policy functions.

At what scale or scales should climate policy be carried out? As the locus of research interest and policy activity shifted rapidly from the global to the local scale, researchers have overlooked the role of metropolitan regions. This spatial mismatch exacerbates the collective action problem for cities. Sustainability encompasses actors across city and county lines linked through shared infrastructure and communication networks. Regional actions also improve the efficiencies of transboundary decisions, coordinating collective goods to achieve economies of scale and reducing the transaction cost of the sustainability programs a city enacts. Regional networks, organizations, and institutions are needed to address the co-benefits of sustainability to enhance positive externalities and provide potential institutional mechanisms to reduce negative externalities. Coordination at a regional scale [5]. This requires cities to act collectively to address climate change, pursue growth in a manner that does not degrade the ecosystem and uses resources efficiently, and ensure that all have opportunity to improve their livelihood. Research on collaborative approaches to environmental management and resource conservation [6], economic development [7], and greater social equity through service delivery [8] demonstrate the importance of a regional approach to policy governance.

While there are different schools of thought within the study of regional governance, most begin with the proposition that collaboration can produce benefits that would be very difficult to generate if a city acted alone. While on the one hand cities are interdependent in that the decisions of one will influence the costs and benefits of other local decisions, on the other hand the potential for free-riding and opportunistic behavior can undermine collaborative efforts. Thus, one of the difficulties of regional governance is the development of institutional mechanisms that reduce the costs of monitoring and enforcing agreed upon solutions to addressing regional problems, while enabling joint benefits to be distributed among cities from coordinated action. From the perspective of institutional analysis, the mechanisms established by local actors to interact and collaborate and through which transactions occur represent the rules that guide behavior and shape policy decisions [1].

\section{References}

1. Feiock R (2013) The Institutional Collective Action Framework. Policy Studies Journal 41(3): 397-425.

2. Ostrom E (2012) Nested Externalities and Polycentric Institutions: Must we Wait for Global Solutions to Climate Change Before Taking Actions at other Scales? Econ Theory 49: 353-369.

3. Feiock R, Bae J (2011) Politics, Institutions, and Entrepreneurship: City Decisions Leading to Inventoried Green House Gas Emissions. Carbon Management 2(4): 443-453.

4. Olson M (1965) The Logic of Collective Action: Public Goods and the Theory of Groups. Cambridge, MA: Harvard University Press, USA.

5. Feiock R, Coutts C (2013) Guest Editors' Introduction: Governing the Sustainable City. Cityscape 15(1): 1-7.

6. Lubell M, Schneider M, Scholz J, Mete M (2002) Watershed Partnerships and the Emergence of Collective Action Institutions. American Journal of Political Science 46(1): 148-163.

7. Hawkins C, Feiock R (2011) Joint Ventures, Economic Development Policy, and the Role of Local Governing Institutions. American Review of Public Administration 41(3): 329-347.

8. LeRoux K, Brandenburger P, Pandey S (2011) Interlocal Service Cooperation in U.S. Cities: A Social Network Explanation. Public Administration Review 70(2): 268-278. 
Your next submission with Juniper Publishers will reach you the below assets

- Quality Editorial service

- Swift Peer Review

- Reprints availability

- E-prints Service

- Manuscript Podcast for convenient understanding

- Global attainment for your research

- Manuscript accessibility in different formats ( Pdf, E-pub, Full Text, Audio)

- Unceasing customer service

Track the below URL for one-step submission https://juniperpublishers.com/online-submission.php 